The University of Southern Mississippi

The Aquila Digital Community

Faculty Publications

6-1-2021

\title{
Brown Meets Green: Light and Nutrients Alter Detritivore Assimilation of Microbial Nutrients From Leaf Litter
}

\author{
Taylor L. Price \\ University of Southern Mississippi, taylor.I.price@usm.edu \\ Jennifer Harper \\ Eastern Michigan University \\ Steven N. Francoeur \\ Eastern Michigan University, steve.francoeur@emich.edu \\ Halvor M. Halvorson \\ University of Southern Mississippi, halvorso@gmail.com \\ Kevin A. Kuehn \\ University of Southern Mississippi, kevin.kuehn@usm.edu
}

Follow this and additional works at: https://aquila.usm.edu/fac_pubs

Part of the Ecology and Evolutionary Biology Commons

\section{Recommended Citation}

Price, T., Harper, J., Francoeur, S., Halvorson, H., Kuehn, K. (2021). Brown Meets Green: Light and Nutrients Alter Detritivore Assimilation of Microbial Nutrients From Leaf Litter. Ecology, 102(6).

Available at: https://aquila.usm.edu/fac_pubs/18837

This Article is brought to you for free and open access by The Aquila Digital Community. It has been accepted for inclusion in Faculty Publications by an authorized administrator of The Aquila Digital Community. For more information, please contact Joshua.Cromwell@usm.edu. 


\title{
Report
}

Ecology, 102(6), 2021, e03358

(C) 2021 by the Ecological Society of America

\section{Brown meets green: light and nutrients alter detritivore assimilation of microbial nutrients from leaf litter}

\author{
Taylor L. Price (iD) ${ }^{1,2}$ Jennifer Harper, ${ }^{3,4}$ Steven N. Francoeur (iD) ${ }^{3}$ Halvor M. Halvorson (iD,${ }^{1,5}$ and \\ KeVIN A. KueHN (iD) 1,6 \\ ${ }^{1}$ School of Biological, Environmental, and Earth Sciences, University of Southern Mississippi, Hattiesburg, Mississippi 39406 USA \\ ${ }^{2}$ Department of Plant and Microbial Biology, University of Minnesota, Saint Paul, Minnesota 55108 USA \\ ${ }^{3}$ Department of Biology, Eastern Michigan University, Ypsilanti, Michigan 48197 USA \\ ${ }^{4}$ Department of Biological Sciences, Bowling Green State University, Bowling Green, Ohio 43403 USA \\ ${ }^{5}$ Department of Biology, University of Central Arkansas, Conway, Arkansas 72035 USA
}

Citation: Price, T. L., J. Harper, S. N. Francoeur, H. M. Halvorson, and K. A. Kuehn. 2021. Brown meets green: light and nutrients alter detritivore assimilation of microbial nutrients from leaf litter. Ecology 102 (6):e03358. 10.1002/ecy.3358

\begin{abstract}
In aquatic detrital-based food webs, research suggests that autotroph-heterotroph microbial interactions exert bottom-up controls on energy and nutrient transfer. To address this emerging topic, we investigated microbial responses to nutrient and light treatments during Liriodendron tulipifera litter decomposition and fed litter to the caddisfly larvae Pycnopsyche sp. We measured litter-associated algal, fungal, and bacterial biomass and production. Microbes were also labeled with ${ }^{14} \mathrm{C}$ and ${ }^{33} \mathrm{P}$ to trace distinct microbial carbon (C) and phosphorus (P) supporting Pycnopsyche assimilation and incorporation (growth). Litterassociated algal and fungal production rates additively increased with higher nutrient and light availability. Incorporation of microbial P did not differ across diets, except for higher incorporation efficiency of slower-turnover $\mathrm{P}$ on low-nutrient, shaded litter. On average, Pycnopsyche assimilated fungal $\mathrm{C}$ more efficiently than bacterial or algal $\mathrm{C}$, and Pycnopsyche incorporated bacterial $\mathrm{C}$ more efficiently than algal or fungal $\mathrm{C}$. Due to high litter fungal biomass, fungi supported $89.6-93.1 \%$ of Pycnopsyche C growth, compared to $0.2 \%$ to $3.6 \%$ supported by bacteria or algae. Overall, Pycnopsyche incorporated the most $\mathrm{C}$ in high nutrient and shaded litter. Our findings affirm others' regarding autotroph-heterotroph microbial interactions and extend into the trophic transfer of microbial energy and nutrients through detrital food webs.
\end{abstract}

Key words: algae; bacteria; carbon; ecological stoichiometry; fungi; phosphorus; Pycnopsyche.

\section{INTRODUCTION}

Classic approaches to trophic ecology have focused on delineating energy and material flow between "brown" and "green" food webs (Lindeman 1942, Brett et al. 2017). Brown food webs are driven by inputs of detrital subsidies and subsequent assimilation and mineralization by microbial decomposers (i.e., fungi and bacteria) that are key to detritivore nutrition (Marks 2019). In turn, green food webs are directly influenced by light availability, which regulates autotroph biomass and nutrient content, and therefore influences upper trophic

Manuscript received 22 September 2020; revised 27 January 2021; accepted 15 March 2021. Corresponding Editor: Helmut Hillebrand.

${ }^{6}$ E-mail: kevin.kuehn@usm.edu levels (Sterner et al. 1997). While green and brown food webs differ in their energy basis, they are both limited by the availability of nutrients (e.g., nitrogen and phosphorus (P)) and play major roles in ecosystem-level energy flow and nutrient cycling (Zou et al. 2016, Evans-White and Halvorson 2017).

In brown food webs, detritivores derive nutrition from both detritus and microbial biomass (Marks 2019). The detrital-microbial matrix consists of diverse microbes, predominantly heterotrophic fungi and bacteria, which may differ in nutritional importance for detritivores (Findlay et al. 2002). Detritivores assimilate most of their nutrition from microbial biomass compared to the detritus itself, due to the higher nutritional value of microbial biomass; for example, fungi colonize and assimilate detrital organic carbon (C) and nutrients into a form more palatable for detritivores to ingest 
and assimilate (Chung and Suberkropp 2009). The detrital substrate is one source of nutrients supporting microbial biomass, but microbes can also assimilate dissolved inorganic nutrients, which allows microbes to increase biomass, growth rates, and nutrient contents with increased inorganic nutrient availability (Manning et al. 2015).

To date, most research within detrital-based food webs has emphasized the nutritional importance of heterotrophic bacteria and fungi to detritivores (e.g., Chung and Suberkropp 2009, Halvorson et al. 2016); however, roles of detrital-associated autotrophic microbes (i.e., algae) remain poorly known. This is due to the assumption that autotrophs play minimal roles in detrital-based food webs, especially in ecosystems of low light availability and low algal biomass, such as headwater streams. Yet, increasing research suggests that algae can play key roles in brown food webs by stimulating heterotrophic activity (Danger et al. 2013, Kuehn et al. 2014, Demars et al. 2020). Moreover, food web data suggest that detritivores partly rely on green energy pathways, suggesting that autotrophs play greater roles in detrital food webs than is classically assumed (Wolkovich et al. 2014). Algae support animal growth across many aquatic systems, likely due to the high nutritional quality of algal amino and fatty acids (Brett et al. 2017). Anthropogenic deforestation and nutrient enrichment have also likely magnified these algal roles in aquatic food webs by removing growth constraints on algae, further motivating research of algal influences on brown food webs (Danger et al. 2013, Kaylor et al. 2016).

Our objective was to determine the effects of light and nutrient availability on the detrital-microbial matrix and subsequent trophic transfer of microbial energy and nutrients to detritivores. We used ${ }^{14} \mathrm{C}$ and ${ }^{33} \mathrm{P}$ as tracers of assimilation and incorporation of detrital microbial C and $\mathrm{P}$ by the detritivorous caddisfly larvae Pycnopsyche sp. We hypothesized that (1) given the comparatively high quality of algal nutrients (Brett et al. 2017), larvae fed light-exposed litter diets would exhibit greater assimilation and incorporation efficiency of autotrophic $\mathrm{C}$ compared to heterotrophic C (bacteria and fungi); (2) Pycnopsyche would increase $\mathrm{P}$ incorporation efficiency on low-nutrient litter diets due to stronger P limitation of growth (Halvorson et al. 2016); and (3) to compensate for lower algal C pools, Pycnopsyche would increase assimilation and incorporation efficiencies of heterotrophic $\mathrm{C}$ on shaded litter. In combination with shifts in consumption, light and nutrient availability would thus alter the contribution of heterotrophic vs. autotrophic microbial nutrients to Pycnopsyche growth.

\section{Methods}

\section{Experimental set-up}

Tulip Poplar (Liriodendron tulipifera) leaves were used in this study because they are a high-quality resource for
Pycnopsyche growth, based on experiments established in previous feeding studies (Chung and Suberkropp 2009). On 8 January 2018 leaf discs were mounted on acrylic plates and conditioned for seven weeks in eight outdoor flume mesocosms at Lake Thoreau Environmental Center using stream water from Big Creek, a second-order forested stream in De Soto National Forest, Mississippi, USA. Four low-nutrient flumes received no nutrient amendments while four high-nutrient flumes received nutrient amendments of $\mathrm{NaNO}_{3}$ and $\mathrm{Na}_{2} \mathrm{HPO}_{4}$ to raise concentrations by $400 \mu \mathrm{g} / \mathrm{L} \mathrm{N}-\mathrm{NO}_{3}$ and $60 \mu \mathrm{g} / \mathrm{L}$ $\mathrm{P}-\mathrm{PO}_{4}$, with new amendments during each water change. Flumes from a given nutrient level shared an aerated recirculating cattle trough, containing $150 \mathrm{~L}$ stream water of which one-third was replaced every $5 \mathrm{~d}$ and set to flow rates of $10 \mathrm{~mL} / \mathrm{s}$ in each flume. All flumes were shaded by mesh canopy to reduce solar heating; each of the eight flumes was divided into half receiving ambient sunlight (light treatment; $51 \%$ and $23 \%$ of ambient photosynthetically active radiation (PAR) and UV, respectively) and half shaded with opaque barrier (shade treatment; PAR and UV below detection). HOBO Onset Loggers (Onset Computer Corporation, Bourne, Massachusetts, USA) monitored temperatures, and after each nutrient amendment, we collected, froze, and thawed and filtered water to measure concentrations of $\mathrm{P}_{-} \mathrm{PO}_{4}, \mathrm{~N}-\mathrm{NH}_{4}$, and $\mathrm{N}-\left[\mathrm{NO}_{3}\right]$ using a SEAL Autoanalyzer 3 (SEAL Analytical, Mequon, Wisconsin, USA). See Appendix S1: Table S1 for flume water physicochemistry.

After conditioning, replicate leaf discs were collected to characterize elemental content, microbial biomass, and production rates in the laboratory (Appendix S2: Table S2). Briefly, litter fungal biomass and production were estimated using the concentration of ergosterol and incorporation of ${ }^{14} \mathrm{C}$-acetate into ergosterol, respectively. The algal taxa, Oedogonium, found in our study, produce ergosterol; however, prior experiments have shown litterassociated Oedogonium ergosterol to be negligible (Kuehn et al. 2014). Algal biomass and production rates were estimated from algal biovolume by microscopy and incorporation of ${ }^{14} \mathrm{C}$-sodium bicarbonate, respectively. Bacterial biomass was quantified by flow cytometry and bacterial production rates were measured using ${ }^{3} \mathrm{H}-\mathrm{leu}-$ cine incorporation into bacterial protein. The methods and conversions used to parcel out biomass of each microbial constituent differ and may introduce bias, but the consistent conversion to units of biomass $\mathrm{C}$ provides best estimates of microbial $\mathrm{C}$ pools for trophic budgeting purposes.

In February 2018, 80 fourth- and fifth-instar larval caddisflies (Pycnopsyche sp.) were collected from Chamber Springs, Arkansas. A subset of 20 caddisflies was removed from their larval cases, blotted, weighed, and frozen to analyze initial elemental contents and dry mass (Appendix S2). The remaining 60 caddisflies were assigned among the four leaf litter diets (incubated under shade or light and low or high nutrients), and 
placed into 60 feeding chambers in an environmental chamber at $15^{\circ} \mathrm{C}$ and a $12 \mathrm{~h}: 12 \mathrm{~h}$ light:dark cycle. Feeding chambers were filled with $100 \mathrm{~mL}$ Chamber Springs water with constant aeration and a 2-mm mesh for accumulation of egesta. Leaf discs used for feeding were well-conditioned and lost $60-70 \%$ of mass during decomposition prior to feeding. Caddisflies were given five unlabeled leaf discs for a 5 -d acclimation period prior to feeding on radiolabeled litter. Two days into the acclimation period, we measured consumption and egestion rates (Appendix S2). After the acclimation, all 60 larvae were transferred to a fume hood at $15^{\circ} \mathrm{C}$ to commence feeding on radiolabeled leaf discs.

Remaining conditioned leaf discs from each of the four diets were assigned to one of three radiolabel methods to label different pools of microbial $\mathrm{C}$ and $\mathrm{P}$, using dual ${ }^{14} \mathrm{C}$ and ${ }^{33} \mathrm{P}$ labeling, prior to feeding (Appendix S2). Briefly, we used ${ }^{14} \mathrm{C}$-bicarbonate to label autotrophic $\mathrm{C}(0.05 \mu \mathrm{Ci} / \mathrm{mL} ; 4 \mathrm{~h}$ labeling $)$, and ${ }^{14} \mathrm{C}$-acetate to label slow-turnover heterotrophic (predominantly fungal) $\mathrm{C}(0.33 \mu \mathrm{Ci} / \mathrm{mL}, 0.25 \mathrm{mmol} / \mathrm{L}$ acetate; 3-d labeling) or fast-turnover heterotrophic (predominantly bacterial) $\mathrm{C}(0.33 \mathrm{nCi} / \mathrm{mL}, 0.25 \mu \mathrm{mol} / \mathrm{L}$ acetate; 1-h labeling). The lower acetate concentration and short duration of fast-turnover label should favor uptake by fast-turnover bacteria, rather than fungi, because bacteria exhibit high affinity for low concentrations of dissolved organic compounds, relative to fungi, which are slower-turnover organisms and less competitive for uptake at low concentrations (Newell 1984). All radiolabel solutions also contained ${ }^{33} \mathrm{P}-\mathrm{PO} 4$ at $0.01 \mu \mathrm{Ci} / \mathrm{mL}$ to label mid-, slow-, or fast-turnover microbial $\mathrm{P}$, respectively. Labeling took place at $15^{\circ} \mathrm{C}$ and $300 \mu \mathrm{mol}$ photons $\cdot \mathrm{m}^{-2} \cdot \mathrm{s}^{-1}$. One killed control was from each diet and radiolabel method to correct for non-biological uptake. Killed controls exhibited low radiolabel uptake, indicating minimal influence of nonbiological uptake (Appendix S2). Radiolabeled discs were rinsed four times with unlabeled water and either frozen to quantify initial ${ }^{14} \mathrm{C}$ and ${ }^{33} \mathrm{P}$, or immediately fed to caddisflies (five discs per chamber) from acclimated diet treatments, randomly assigned one of the three radiolabel methods.

Caddisflies were provided radiolabeled discs in a fume hood for 36-48 h. Residual leaf material was frozen to determine post-consumption radiolabel remaining. We filtered accrued egesta onto $25-\mathrm{mm}$ glass fiber filters and froze the filters to determine egested ${ }^{14} \mathrm{C}$ and ${ }^{33} \mathrm{P}$. Concluding the feeding study, we provided caddisflies with $100 \mathrm{~mL}$ fresh stream water and five unlabeled leaf discs for a 24-h period to egest excess radiolabel (Chung and Suberkropp 2009). Accumulated egesta were again collected. Caddisflies were pulled from feeding chambers, removed from their cases, rinsed three times with stream water, blotted, weighed, and frozen. Samples were then processed to determine total ${ }^{14} \mathrm{C}$ and ${ }^{33} \mathrm{P}$ disintegrations per minute (DPMs) (Halvorson et al. 2016; Appendix S2).

\section{Calculations and data analysis}

Total ${ }^{14} \mathrm{C}$ and ${ }^{33} \mathrm{P}$ DPMs consumed by each caddisfly was calculated from the total of each radioisotope fed to caddisflies (average DPMs per disc, multiplied by five discs), minus ${ }^{14} \mathrm{C}$ and ${ }^{33} \mathrm{P}$ of residual material. Total DPMs egested and incorporated were determined as ${ }^{14} \mathrm{C}$ or ${ }^{33} \mathrm{P}$ DPMs in egesta and caddisfly samples, respectively. We calculated ${ }^{14} \mathrm{C}$ - and ${ }^{33} \mathrm{P}$-specific assimilation efficiencies using

Assimilation efficiency $=\frac{\text { DPMs consumed }- \text { DPMs egested }}{\text { DPMs consumed }}$

and ${ }^{14} \mathrm{C}$ - and ${ }^{33} \mathrm{P}$-specific incorporation efficiencies using

$$
\text { Incorporation efficiency }=\frac{\text { DPMs incorporated }}{\text { DPMs consumed }} .
$$

We used a mixing model to quantify assimilation and incorporation efficiency for bacterial and fungal $\mathrm{C}$ separately (Appendix S2). We used microbial biomass and production rates, along with Pycnopsyche consumption rates and efficiency of assimilation and incorporation of microbial C, to quantify C flows to Pycnopsyche on each diet (Appendix S2).

Effects of light and nutrient treatments on conditioned leaf litter microbial biomass and production rates were analyzed using a full factorial two-way analysis of variance (ANOVA). Acclimation consumption and egestion rates were analyzed similarly. Diet effects on larval ${ }^{33} \mathrm{P}$ - and ${ }^{14} \mathrm{C}$-specific assimilation and incorporation efficiencies were also assessed using two-way ANOVA (separate ANOVA for each radiolabel method). Finally, we used one-way ANOVA to analyze differences in assimilation and incorporation efficiency of microbial $\mathrm{C}$ and $\mathrm{P}$ across radiolabel pools (algal, bacterial, or fungal $\mathrm{C}$ and slow-, mid-, or fast-turnover P). Tukey's Honestly Significant Difference tests were used to compare groups when treatment effects were significant. Response variables were log-transformed as necessary to improve variance homogeneity. All analyses were conducted using the statistical program $\mathrm{R}$, version 3.4.3 (R Core Team 2018).

\section{RESULTS}

\section{Microbial biomass and activity}

On conditioned litter, algal biomass was significantly greater in the light compared to the shade $\left(F_{1,12}=78.0\right.$; $P<0.001)$, but did not differ between nutrient treatments (Fig. 1A). Algal production rates similarly increased in the light treatment $\left(F_{1,12}=125.0, \quad P<0.001\right)$, but also responded positively to higher nutrients $\left(F_{1,12}=35.8\right.$, $P<0.001)$, resulting in the greatest rates in the high-nutrient light treatment (Fig. 1B). Bacterial biomass did not 

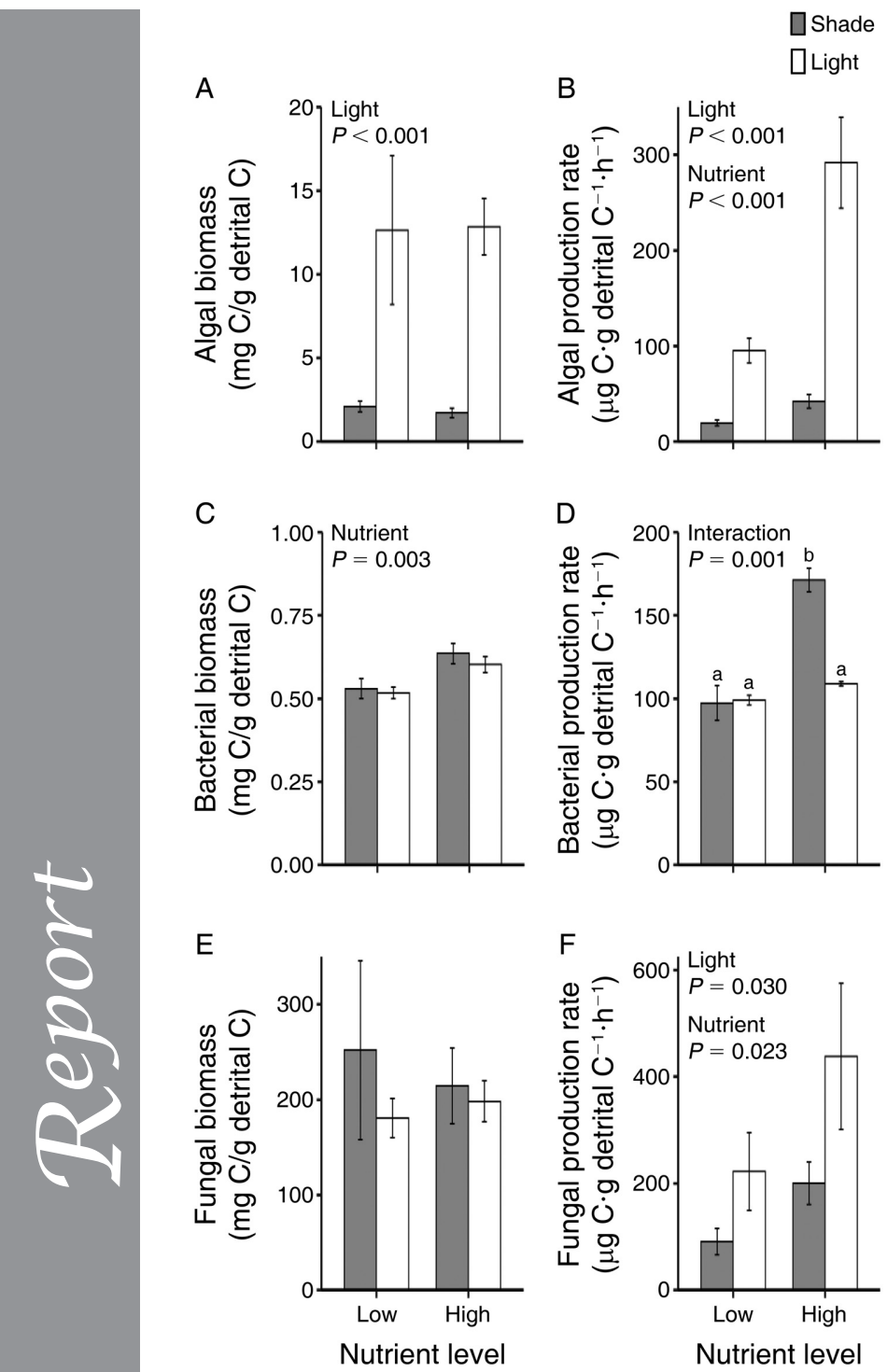

FIG. 1. (A) Algal biomass, (B) algal production rates, (C) fungal biomass, (D) fungal production rates, (E) bacterial biomass, and (F) bacterial production rates on Liriodendron tulipifera leaf litter conditioned under contrasting light and nutrient treatments. Values are mean $\pm \mathrm{SE}$. Treatments and $P$ values within each panel indicate significant effects (ANOVA, $P<0.05)$ and lowercase letters designate group differences across treatments (Tukey HSD, $P<0.05$ ) where interactions were significant.

differ between light treatments, but increased in the highnutrient treatment $\left(F_{1,12}=13.5, P=0.003\right.$; Fig. $\left.1 \mathrm{C}\right)$. Bacterial production rates exhibited a significant light-nutrient interaction $\left(F_{1,12}=18.1, P=0.001\right)$ with the high-nutrient shaded treatment showing higher bacterial production (Fig. 1D). Fungal biomass did not differ across light or nutrient treatments (Fig. 1E) but, much like algal production rates, fungal production exhibited positive additive effects of both light and high nutrients $\left(F_{1,12}=6.1\right.$,
$P=0.030$ and $F_{1,12}=6.8, P=0.023$, respectively; Fig. 1 F). High-nutrient litter exhibited greater percent $P$ but similar percent $\mathrm{N}$ contents compared to low-nutrient litter (Appendix S1: Table S2). Litter algal communities in the light treatment were composed primarily of green algae (Chlorophyta, e.g., Oedogonium) and diatoms (Heterokontophyta, e.g., Navicula; Appendix S1: Table S3).

\section{Dietary effects on acquisition of microbial $C$ and $P$}

Pycnopsyche consumption rates were greater on highnutrient litter $\left(F_{1,56}=6.3, P=0.015\right)$, but declined on light-conditioned litter $\left(F_{1,56}=5.8, P=0.019\right.$; Appendix S1: Fig. S1A). Egestion rates closely reflected consumption rates and responded positively to nutrients $\left(F_{1,56}=7.1, P=0.010\right)$, but light treatment effects were not statistically significant (Appendix S1: Fig. S1B).

Pycnopsyche assimilated algal $\mathrm{C}$ more efficiently on low-nutrient litter compared to high-nutrient litter $\left(F_{1,16}=10.2, P=0.006 ;\right.$ Appendix S1: Fig. S2A), and incorporated algal $\mathrm{C}$ more efficiently on the shade litter compared to the light treatment litter $\left(F_{1,15}=9.4\right.$, $P=0.008$; Appendix S1: Fig. S2B). Assimilation of bacterial $\mathrm{C}$ was more efficient on the shade litter $\left(F_{1,16}=16.1, P<0.001 ;\right.$ Appendix S1: Fig. S2C $)$ while efficiency of incorporating bacterial $\mathrm{C}$ was significantly higher on the low-nutrient litter $\left(F_{1,16}=5.4, P=0.033\right.$; Appendix S1: Fig. S2D). Neither assimilation nor incorporation efficiencies of fungal $\mathrm{C}$ differed across litter treatments (Appendix S1: Fig. S2E, F).

Pycnopsyche assimilated and incorporated fast- and mid-turnover microbial $\mathrm{P}$ similarly across treatments (Appendix S1: Fig. S3A-D). Light-nutrient interactions affected Pycnopsyche assimilation $\left(F_{1,15}=5.2\right.$, $P=0.038)$ and incorporation $\left(F_{1,16}=13.1, P=0.002\right)$ of slow-turnover microbial P. Assimilation efficiency was lowest and incorporation efficiency was greatest for slow-turnover microbial $\mathrm{P}$ on the low-nutrient shade litter (Appendix S1: Fig. S3E, F).

\section{Microbial $C$ and $P$ flows to Pycnopsyche}

Results from one-way ANOVA indicated that, across all diets, Pycnopsyche assimilated fungal $\mathrm{C}$ significantly more efficiently compared to assimilation of algal or bacterial C, equating to $19.0 \%$ and $27.2 \%$ greater efficiency, respectively, of assimilating fungal $\mathrm{C}\left(F_{2,57}=\right.$ $19.9, P<0.001 ;$ Fig. 2A). By comparison, Pycnopsyche incorporation efficiency of microbial $\mathrm{C}$ was markedly lower among all microbial pools, and Pycnopsyche incorporated bacterial $\mathrm{C}$ significantly more efficiently compared to fungal or algal $\mathrm{C}$, representing $12.0 \%$ and $16.5 \%$ greater efficiency, respectively, of incorporating bacterial $\mathrm{C}\left(F_{2,56}=11.8, P<0.001\right.$; Fig. $\left.2 \mathrm{~B}\right)$.

Across all diets, ANOVA results indicated that Pycnopsyche assimilated microbial $\mathrm{P}$ with similar efficiency across the radiolabel pools differing in $\mathrm{P}$ turnover rate $\left(F_{2,55}=0.2, P=0.792\right.$; Fig. 2 C $)$, with mean \pm SE $P$ 
A

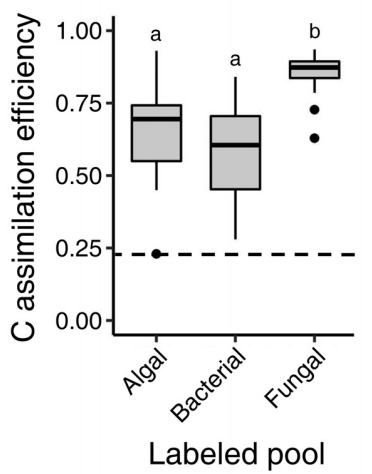

C

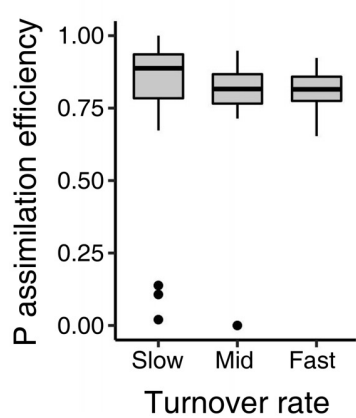

B

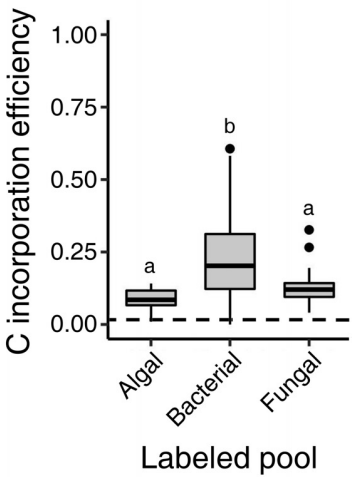

D

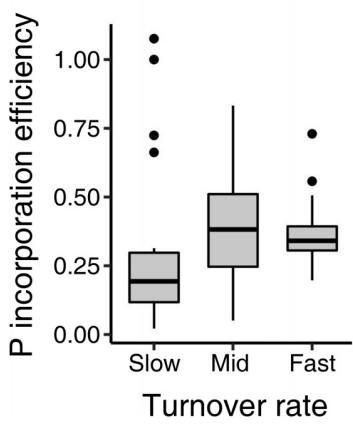

FIG. 2. Box-and-whisker plots of Pycnopsyche (A) C assimilation efficiencies, (B) C incorporation efficiencies, (C) $\mathrm{P}$ assimilation efficiencies, and (D) $\mathrm{P}$ incorporation efficiencies across different labeled microbial $\mathrm{C}$ and $\mathrm{P}$ pools. Box mid lines show medians, box edges show the 1st and 3rd quartile, whiskers show the range out to maximum 1.5 times the interquartile range, and points show values outlying the maximum whisker range. Horizontal dashed lines in panels A and B reference assimilation and incorporation efficiencies assumed for detrital C (see Appendix S2). Lowercase letters designate statistically significant differences across pools (Tukey HSD, $P<0.05)$.

assimilation efficiency of $0.78 \pm 0.03$. By comparison, Pycnopsyche incorporated microbial $\mathrm{P}$ less efficiently $(0.35 \pm 0.03)$, and $\mathrm{P}$ incorporation efficiency also did not differ across turnover rates $\left(F_{2,56}=0.7, P=0.505\right.$; Fig. 2D).

Despite the wide range of $\mathrm{C}$ flows within the detritalmicrobial matrix and to Pycnopsyche assimilation and incorporation of microbial C (Fig. 3), high litter-associated fungal biomass, compounded with the relatively high efficiency of assimilating and incorporating fungal $\mathrm{C}$, resulted in fungal $\mathrm{C}$ being consistently the dominant microbial pool contributing to Pycnopsyche assimilation and growth. While diet treatment affected algal and bacterial $\mathrm{C}$ flows, these flows were always lower than fungal or detrital $\mathrm{C}$ flows. Our calculations suggest that Pycnopsyche incorporated the most $\mathrm{C}$ on the high-nutrient shade conditioned litter.

\section{Discussion}

By employing dual tracers to label contrasting pools of microbial $\mathrm{C}$ and $\mathrm{P}$, our study helps resolve the nutritional value of detrital microbial biomass and shows bottom-up effects of light and dissolved nutrients on acquisition of microbial nutrients by detritivores. On average, Pycnopsyche assimilated and incorporated heterotrophic microbial $\mathrm{C}$ at higher efficiencies than autotrophic microbial $\mathrm{C}$, refuting our first hypothesis that autotrophic $\mathrm{C}$ would be of greater value compared to heterotrophic C. While incorporation of fast- and mid-turnover microbial $\mathrm{P}$ did not show dietary effects, incorporation of slow-turnover microbial $\mathrm{P}$ expressed higher efficiencies under shaded low-nutrient conditions, supporting hypothesis 2. Finally, only assimilation of bacterial $\mathrm{C}$ was significantly more efficient in the shade treatment, and incorporation of fungal $\mathrm{C}$ was on average higher on the light treatment diets, lending weak support to hypothesis 3 . The results indicate that microbes differ in bulk $\mathrm{C}$ quality, but we acknowledge microbial pools can also be high-quality by providing essential micronutrients such as fatty and amino acids, which were a small proportion of labeled C (Brett et al. 2017, Trochine et al. 2020). Overall, our findings suggest that environmental factors like light and nutrients are bottom-up controls not only on the magnitude, but also the nutritional quality, of detrital microbial biomass, which constrains energy and nutrient flow at the base of brown food webs.

Our study affirms others' showing that light and dissolved nutrients affect biomass and activity of detrital microbes at the base of the brown food web (Danger et al. 2013). Detrital algal biomass and production increased strongly with light exposure, as did fungal production, suggesting algae directly stimulated heterotrophy, likely by provisioning labile $\mathrm{C}$ exudates to fungi (Kuehn et al. 2014, Halvorson et al. 2019). Conversely, bacterial production was higher under shaded and highnutrient conditions, suggesting bacterial activity was reduced by algal photosynthesis, perhaps due to competition with algae for dissolved nutrients (Wyatt et al. 2019). Together, these findings suggest that algal activity can shift microbial biomass and $\mathrm{C}$ flows within the detrital-microbial matrix, potentially affecting detritivore nutrition and growth.

Consumption and assimilation determine the amount of energy and nutrients available to support animal growth. In the present study, Pycnopsyche consumption and egestion rates increased on high-nutrient litter compared to low-nutrient litter, consistent with previous findings (Evans-White and Halvorson 2017). This may be explained by a release from nutrient limitation and increased feeding rates and throughput on high-quality microbial biomass. Pycnopsyche also decreased consumption rates on light-conditioned litter, suggesting this litter was less palatable, perhaps due to a shift in the fungal assemblage (Arsuffi and Suberkropp 1989), or as a compensatory response to raise assimilation (see similar

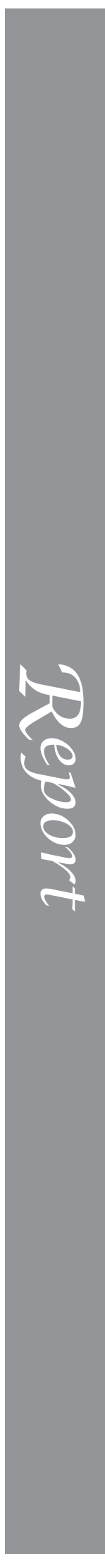



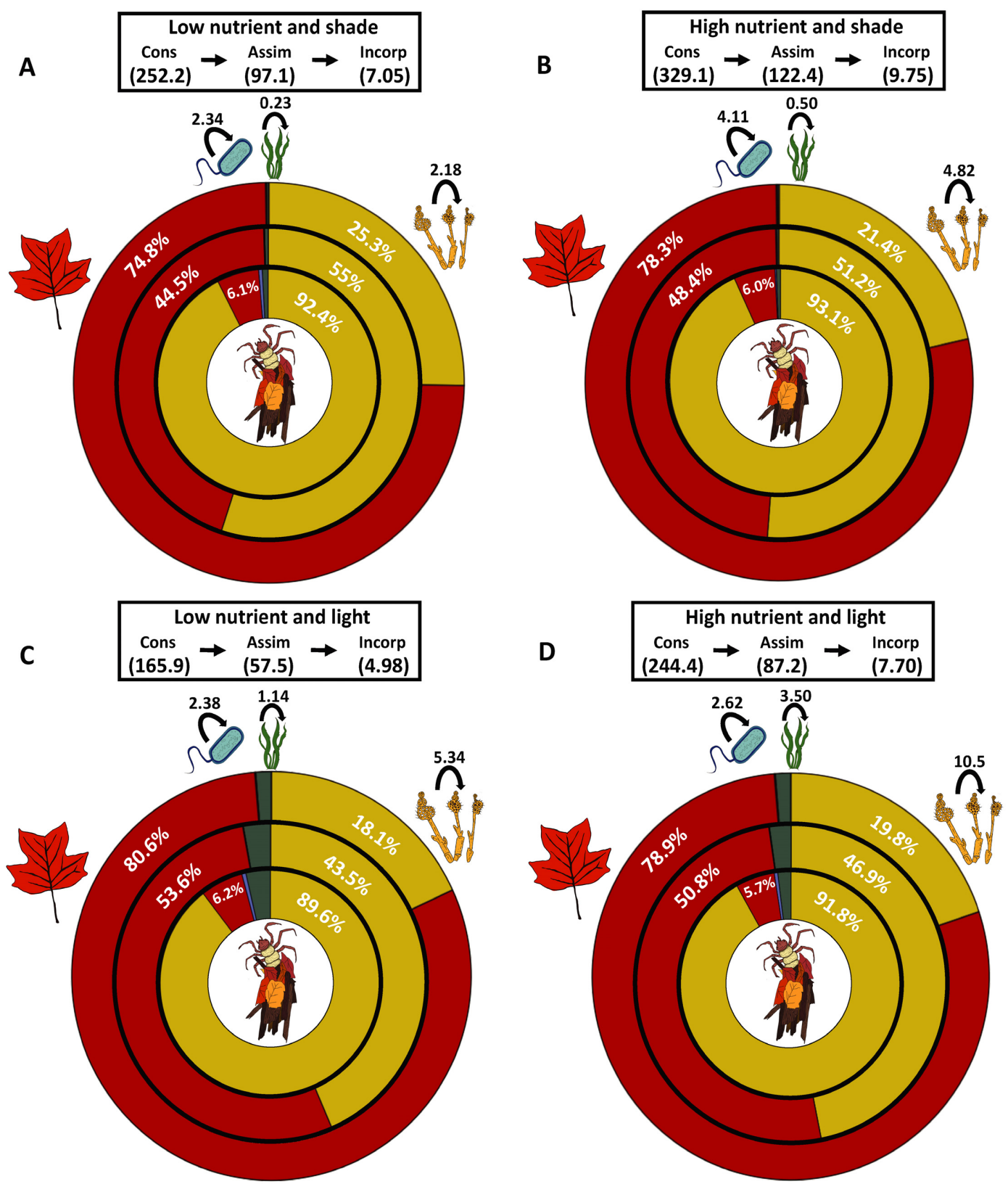

FIG. 3. Summary of C flows within the detrital-microbial matrix and to Pycnopsyche. All microbial flows are in units of mg C.g detrital $\mathrm{C}^{-1} \cdot \mathrm{d}^{-1}$ (production rates; curved arrows). Quantitative total $\mathrm{C}$ flows to Pycnopsyche consumption (Cons), assimilation (Assim), and incorporation (Incorp) are identified at the top of each panel, associated, respectively, with the outermost, middle, and inner concentric circles in each panel. Flows are designated as detrital (red), bacterial (blue), algal (green), or fungal (yellow) in units of mg C.g Pycnopsyche $\mathrm{C}^{-1} \cdot \mathrm{d}^{-1}$ based on microbial biomass, Pycnopsyche consumption rates, and Pycnopsyche microbial C assimilation and incorporation efficiency (also see Appendix S1: Table S4). Panels are organized by diet treatment: (A) low-nutrient shade, (B) high-nutrient shade, (C) low-nutrient light, and (D) high-nutrient light. See Methods and Appendix S2 for a description of flow budget calculations.

egestion despite slower consumption rates on light treatments). Increased feeding could have also occurred as a compensatory response on high-nutrient, shaded litter due to an inability of Pycnopsyche to increase assimilation efficiency on this litter. Although greater consumption may elevate growth rates, efficiencies of assimilation and incorporation, particularly of high-quality microbial biomass, ultimately determine energy and nutrient flows toward detritivore growth (Marks 2019).

The assimilation and incorporation efficiency of resources are useful metrics in determining the fate of $\mathrm{C}$ in consumer nutritional budgets. Particularly, assimilation efficiency provides information on the energy or $\mathrm{C}$ used in rapid metabolic processes. Incorporation 
efficiency quantifies nutrients put towards long term structural growth. Comparisons between Pycnopsyche assimilation and incorporation across microbial pools allowed us to parcel out the microbial contributions to detritivore energy and nutrient demands between varying treatments. Across all diets, fungal $\mathrm{C}$ was the highestquality for assimilation, but bacterial $\mathrm{C}$ was the highestquality for incorporation. The observed results may be explained by the presence of secondary metabolites produced by fungi to deter animal consumption (Arsuffi and Suberkropp 1989). Secondary metabolites may be energetically expensive for Pycnopsyche to metabolize and increase the incorporation of $\mathrm{C}$ from bacterial pools. Furthermore, differences in the molecular compounds produced between bacteria and fungi may impact incorporation efficiency. For instance, bacteria may offer a unique suite of amino acids to Pycnopsyche that are absent or at lower concentrations in fungal cells (Larsen et al. 2009). Future studies should address differences in microbial taxonomic assemblages between light and nutrient treatments, as this may influence the microbial nutritional quality to aquatic consumers.

Surprisingly, autotrophic $\mathrm{C}$ was assimilated and incorporated with lower efficiency, suggesting that although algae may provide essential micronutrients (Brett et al. 2017; Trochine et al. 2020), algae are likely not the bulk of high-quality $\mathrm{C}$ supporting detritivore growth even on light-conditioned litter. Across diets, $89.6-93.1 \%$ of estimated Pycnopsyche $\mathrm{C}$ incorporation was from fungi, whereas bacteria supported $0.2-0.6 \%$ and algae supported $0.6-3.6 \%$ of Pycnopsyche $\mathrm{C}$ incorporation (Fig. 3). Although our results indicate fungal $\mathrm{C}$ is easily digested, the majority of ingested fungal $\mathrm{C}$ is ultimately lost post-assimilation, likely to respiration. Lower assimilation efficiencies of bacterial $\mathrm{C}$ may be due to small bacterial cells entrained away from digestive activity within the detrital matrix, lowering assimilation efficiency, or possibly due to low litter bacterial biomass that may cause the Pycnopsyche gut to bias digestion of fungal rather than bacterial C. Still, bacterial C appears to be high quality for direct incorporation into animal biomass, as indicated by higher incorporation efficiencies. Overall, our data highlight the quantitative importance of fungal $\mathrm{C}$, relative to bacterial or algal $\mathrm{C}$, in supporting detritivore growth across a range of diets (Chung and Suberkropp 2009).

Detritivore acquisition of microbial $\mathrm{P}$ is likely a major constraint on detritivore growth, because microbes provide a major pool of $\mathrm{P}$ available to detritivores relative to the P-deplete detrital substrate (Manning et al. 2015, Halvorson et al. 2016). Our ${ }^{33} \mathrm{P}$ labeling methods did not distinguish microbial pools and thus labeled a consortium of microbes simultaneously, but diet treatments and turnover times should have resulted in a wide range of microbial P pools labeled. For example, fast-turnover $\mathrm{P}$ pools are more likely associated with cellular growth, such as ribosomal RNA, whereas slow-turnover P pools are more likely associated with $\mathrm{P}$ storage molecules such as polyphosphate, which both fungi and algae may store (Rier et al. 2016). Biomass production between the different microbial pools can also lead to changes in the bioavailability of $\mathrm{P}$ to aquatic consumers. For instance, competitive interactions between algae and fungi at longer time scales may lead to $\mathrm{P}$ storage that is less available for consumer incorporation. The microbial pools may differ in nutritional quality of $\mathrm{P}$ molecules and drive the patterns observed in our study, namely a trend of increasing $\mathrm{P}$ incorporation efficiency on the low-nutrient shade-treatment diet and among faster-turnover P pools. Future work should address the roles of algal vs. fungal P storage within the detrital-microbial matrix, particularly given $\mathrm{P}$ is an important bottom-up control in brown food webs (Demi et al. 2018).

Our study used novel radiolabel methods to untangle interactions within the detrital-microbial matrix under contrasting environmental conditions. As such, we showed that light and nutrient availability influence both microbial interactions and transfer of microbial $\mathrm{C}$ and $\mathrm{P}$ to detritivores. Fungal $\mathrm{C}$ was the largest contributor to detritivore growth, even on light-conditioned litter with substantial algal biomass and activity. Direct algal contributions to $\mathrm{C}$ flow into brown food webs may thus be relatively small. Still, algal influence on detrital food webs may be substantial, if indirectly mediated by algalinduced shifts in fungal biomass, activity, or species assemblage (Halvorson et al. 2019). For example, algae may provision labile $\mathrm{C}$ to heterotrophs, providing a flow path ultimately supporting detritivores, alternative to detrital substrate C (Kuehn et al. 2014). On average, Pycnopsyche assimilated and incorporated microbial $\mathrm{P}$ more efficiently than microbial $\mathrm{C}$, highlighting the importance of microbial $\mathrm{P}$ for invertebrate growth (Halvorson et al. 2016, Demi et al. 2018). Further work must parcel out biomolecules that explain varying microbial $\mathrm{P}$ quality. We acknowledge our assumptions that Pycnopsyche did not feed selectively on microbial biomass, and that radiolabel ${ }^{14} \mathrm{C}$ did not transfer across microbial pools during labeling (e.g., label transfer from autotrophs to heterotrophs via exudation, or internal cycling of labeled $\mathrm{CO}_{2}$; Demars et al. 2020). While these processes merit investigation, the controlled and relatively short labeling conditions, especially of algae and bacteria, should have limited these dynamics during our study. Toward untangling trophic pathways within detrital food webs, our results provide a new, quantitative view into the role of green vs. brown flow paths in driving microbial interactions and trophic transfer in many ecosystems.

\section{AcKNOWLEDGMents}

We thank the Kuehn lab, M. Davis, and J. Schaefer. This research was supported by Lake Thoreau Environmental Center and the United States NSF, DEB \#1457217 and DBI \#0923063. 


\section{Literature Cited}

Arsuffi, T. L., and K. Suberkropp. 1989. Selective feeding by shredders on leaf-colonizing stream fungi: comparison of macroinvertebrate taxa. Oecologia 79:30-77.

Brett, M. T., et al. 2017. How important are terrestrial organic carbon inputs for secondary production in freshwater systems? Freshwater Biology 62:833-853.

Chung, N., and K. Suberkropp. 2009. Contribution of fungal biomass to the growth of the shredder, Pycnopsyche gentilis (Trichoptera: Limnephilidae). Freshwater Biology 54:2212-2224.

Danger, M., J. Cornut, E. Chauvet, P. Chavez, A. Elger, and A. Lecerf. 2013. Benthic algae stimulate leaf litter decomposition in detritus-based headwater streams: A case of aquatic priming effect? Ecology 94:1604-1613.

Demars, B. O. L., N. Friberg, and B. Thornton. 2020. Pulse of dissolved organic matter alters reciprocal carbon subsidies between autotrophs and bacteria in stream food webs. Ecological Monographs 90:e01399.

Demi, L. M., J. P. Benstead, A. D. Rosemond, and J. C. Maerz. 2018. Litter $P$ content drives consumer production in detritus-based streams spanning an experimental N:P gradient. Ecology 99:347-359.

Evans-White, M. A., and H. M. Halvorson. 2017. Comparing the ecological stoichiometry in green and brown food websa review and meta-analysis of freshwater food webs. Frontiers in Microbiology 8:1184.

Findlay, S., et al. 2002. A cross-system comparison of bacterial and fungal biomass in detritus pools of headwater streams. Microbial Ecology 43:55-66.

Halvorson, H. M., J. R. Barry, M. B. Lodato, R. H. Findlay, S. N. Francoeur, and K. A. Kuehn. 2019. Periphytic algae decouple fungal activity from leaf litter decomposition via negative priming. Functional Ecology 33:188-201.

Halvorson, H. M., G. White, J. T. Scott, and M. A. EvansWhite. 2016. Dietary and taxonomic controls on incorporation of microbial carbon and phosphorus by detritivorous caddisflies. Oecologia 180:567-579.

Kaylor, M. J., D. R. Warren, and P. M. Kiffney. 2016. Longterm effects of riparian forest harvest on light in Pacific Northwest (USA) streams. Freshwater Science 36:1-13.

Kuehn, K. A., S. N. Francoeur, R. H. Findlay, and R. K. Neely. 2014. Priming in the microbial landscape: periphytic algal stimulation of litter-associated microbial decomposers. Ecology 95:749-762.
Larsen, T., D. L. Taylor, M. B. Leigh, and D. M. O’Brien. 2009. Stable isotope fingerprinting: a novel method for identifying plant, fungal, or bacterial origins of amino acids. Ecology 90:3526-3535.

Lindeman, R. L. 1942. The trophic-dynamic aspect of ecology. Ecology 23:399-418.

Manning, D. W. P., A. D. Rosemond, J. S. Kominoski, V. Gulis, J. P. Benstead, and J. C. Maerz. 2015. Detrital stoichiometry as a critical nexus for the effects of streamwater nutrients on leaf litter breakdown rates. Ecology 96:2214-2224.

Marks, J. C. 2019. Revisiting the fates of dead leaves that fall into streams. Annual Review of Ecology, Evolution, and Systematics 50:547-568.

Newell, S. Y. 1984. Bacterial and fungal productivity in the marine environment: a contrasting overview. Colloques Internationaux Centre National Recherches Scientifique (Marseilles) 331:133-139.

R Core Team. 2018. R: a language and environment for statistical computing. R Foundation for Statistical Computing, Vienna, Austria. http://www.R-project.org/

Rier, S. T., K. C. Kinek, S. E. Hay, and S. N. Francoeur. 2016. Polyphosphate plays a vital role in the phosphorus dynamics of stream periphyton. Freshwater Science 35:490-502.

Sterner, R. W., J. J. Elser, E. J. Fee, S. J. Guildford, and T. H. Chrzanowski. 1997. The light: nutrient ratio in lakes: The balance of energy and materials affects ecosystem structure and process. American Naturalist 150:663-684.

Trochine, C., V. D. Villanueva, and M. T. Brett. 2020. The ultimate peanut butter on crackers for Hyalella: diatoms on macrophytes rather than bacteria and fungi on conditioned terrestrial leaf litter. Freshwater Biology 66:599-614.

Wolkovich, E. M., S. Allesina, K. L. Cottingham, J. C. Moore, S. A. Sandin, and C. Mazancourt. 2014. Linking the green and brown worlds: the prevalence and effect of multichannel feeding in food webs. Ecology 95:3376-3386.

Wyatt, K. H., R. C. Seballos, M. N. Shoemaker, S. P. Brown, S. Chandra, K. A. Kuehn, A. R. Rober, and S. Sadro. 2019. Resource constraints highlight complex microbial interactions during lake biofilm development. Journal of Ecology 107:2737-2746.

Zou, K., E. Thébault, G. Lacroix, and S. Barot. 2016. Interactions between the green and brown food web determine ecosystem functioning. Functional Ecology 30:1454-1465.

\section{SUPPORTING INFORMATION}

Additional supporting information may be found in the online version of this article at http://onlinelibrary.wiley.com/doi/ 10.1002/ecy.3358/suppinfo 